\title{
Natural Motifs on Jepara Batik Products: Symbols of environmental awareness
}

\author{
Siti Maziyah, Alamsyah*, \\ Department History, Faculty of Humanities, Diponegoro University, Semarang - Indonesia
}

\begin{abstract}
Batik Jepara has been around for a long time. The historical evidence was traced back to Kartini's era, in the beginning of the 20th century. During that time Jepara batik was developed and promoted at national and international levels through exhibitions. In its journey, Jepara batik suffered suspended animation and just reappeared around the beginning of 21 st century. During this period several batik artisans who made batik products emerged either based on culture, animals, plants, nature, or other motives. The motifs applied to the batik products that use natural motifs, both flora and fauna, indicates that the craftsmen have awareness to Jepara natural conditions. These natural motifs users symbolically showed the craftsman's concern for the environmental sustainability on land and sea found in Jepara.
\end{abstract}

Keywords: Batik, Jepara, Motifs, Symbols, Nature

\section{Introduction}

Jepara is not an area that become the main center of batik in Java. Nevertheless, batik skills have been existed in various places in Java [1]. From the historical side, the existence of Jepara batik was influenced by a palace because this area once was part of Mataram Islam Kingdom [2]. In early 20th century, Jepara batik existence cannot be separated from R. A. Kartini's role. She extensively introduced the existence of Jepara batik, carving, and weaving [3]. After Kartini era, Jepara batik suffered suspended animation, and just began to develop in early 21 st century. This is marked by the emergence of batik craftsmen who are scattered in almost all regions of Jepara.

In implementing batik products, the craftsmen have environmental awarness, one of them is the usage of batik dyes which made from natural materials in order to reduce pollution [4]. From the motifs aspect, the craftsmen awarness towards the environment is reflected through the application of various environmental motifs that are around Jepara. Many batik products motifs are related to natural elements both on land and at sea. Batik that apply natural elements is adapted to Jepara's geographical location as a coastal area with a long coastline combined with mountainous regions. Batik motifs that take natural

\footnotetext{
* Corresponding author: alam mahir@yahoo.com
} 
motifs are a reflection of the craftsmen's awarness for environmental sustainability in Jepara.

\section{Method}

Writing data used in this study are observation, interviews, visits to regional archives, and literature review both online and library visits [5]. Information relating to batik motifs that applying natural elements is done through direct observation to the field to see the object of batik products studied [6]. The observation aims to obtain a more complete description about batik motif, philosophical foundation, and the conditions underlying the motif appearance [7]. In this process in-depth interviews with the batik craftsmen is also held to find out the philosophy of each batik motif with natural elements [8]. This source collection process combines primary and secondary sources [9]. Primary sources were obtained from observations, searching government or individual archives, and interviewing with batik craftsmen. The interview results show that natural motifs applied in batik products has philosophical meaning. While the secondary sources are obtained from relevant writings such as books, journals, other literature. The Secondary sources were obtained from libraries, private collections, and internet. The available sources are then criticized and interpreted. The results of the analysis above are then linked and reconstructed into an article about "Nature Motifs in Jepara Batik Products: Symbols of Environmental Awarness.

\section{Results and Discussion}

\subsection{Tracing Batik Jepara Track}

Jepara Batik was traced because of the legacy of batik products made during Kartini period. However, based on the oral story that still needs to be proven, the existence of batik in Jepara is marked by Kalyaga batik cloth existence. This cloth is one of the most popular cloth in Jepara. The narrative tells us that the Kalyaga cloth with a nursery pattern (seeding) was made by Kalinyamat Queen to be presented to Joko Tingkir [10]. Kalyaga is a term derived from the Old Javanese, which refers to a type of red woven cloth made from kalyaga tree bark dye [11]. Batik in Jepara in the next period was connected with the Jepara rulers who came from the Islamic Mataram Kingdom, so it was not surprising that Jepara batik motifs have soga color, typical colors of Mataram batik style. Batik motifs with Soga color can be found in batik made by R.A. Kartini in the early 20th century [12].

R.A. Kartini introduced Jepara batik to the world at the National Exhibition for Women's Work in The Hague in 1898. Kartini also popularized Jepara batik through her Dutch scripts writing about how to make batik. Kartini's writing refers to batik making experience and it bases on research on batik craftsmen in Jepara [13]. After getting married and moving to Rembang, Kartini still continued making batik. Batik activity in Jepara began to decreased after Kartini's death [14]. In the Kartini period, batik cloth products were used for own need, family, and exhibited. After that batik activities in Jepara began to decrease

If there were batik activities carried out by Kartini students, R.A. Suci, the aimed is more likely to meet her own family needs. Some of batik motifs made are Parang, Gondosuli, Buketan, Parang Kanthil, Lung, Kanthil, and Broken Coffee Beans [15].

After experinced suspended animation, batik activity began to emerge at the beginning 21 st century pioneered by Suyanti Jatmiko. He tried to develop batik with very diverse motifs and collaborate it with motifs in Jepara such as plants and marine life [16]. To 
develop Jepara batik, Suyanti trained and formed a community that focused on fostering batik craftsmen. Through this community, batik activities can be done by the craftsmen independently. Biyung Pralodho community had 16 members and all of them have succeeded in producing and marketing batik. The community succeeded to develop rapidly because of the craftsmen's hard work and the support from the government of Jepara Regency.

\subsection{Natural Motifs on Batik Products}

Motif is the base or principal of a pattern, because after being drafted and spreaded repeteadly it will form a pattern [17]. Motif is the main element of an ornament. The themes or the basic ideas can be recognized through motifs which are compositions of nature design or as natural representations that are visible, imaginary, abstracts, and others [18]. Several ways to create motif first, stylization that is drawing motifs by giving style to the object's form. Second, distortion that is drawing the motif by exaggerating the object's form. Third, transformation that is drawing motif by moving other elements of the object to the object that being drawn. Fourth, deformation that is drawing motif by only taking certain elements from an object that is considered to represent the character [19].

Batik motifs have characteristics that distinguish them from other traditional motifs with the exploitation of isen-isen (filling pattern) [20]. Batik motifs can be classified into various types, for example human motifs, technological objects, creations, animals, plants, and natural objects [21]. Jepara batik motifs that have natural environment elements of land and sea can be classified in motifs of animals, plants, and natural objects.

\subsubsection{Animal Motifs}

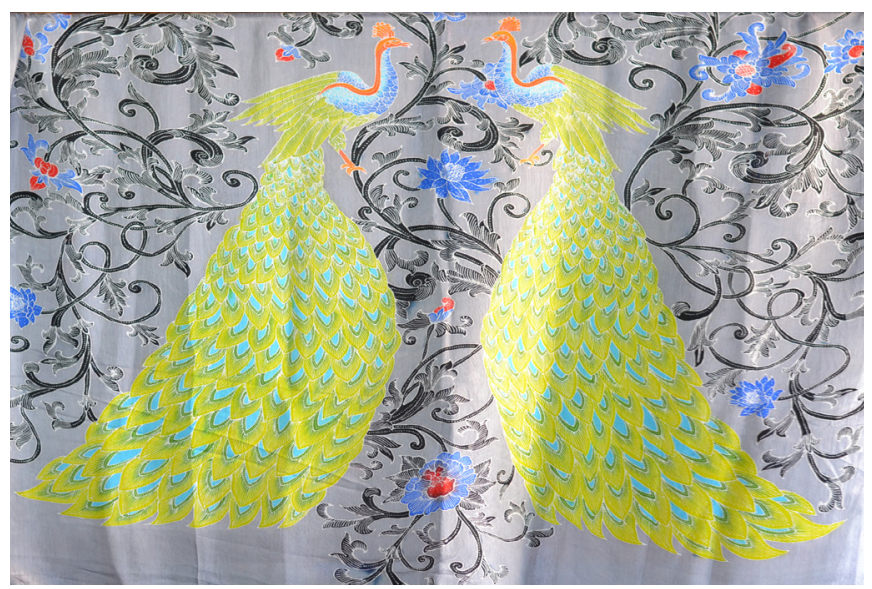

Fig. 1. Peacock Motif (by Suyanti) (Author's Documentation, 2019) 


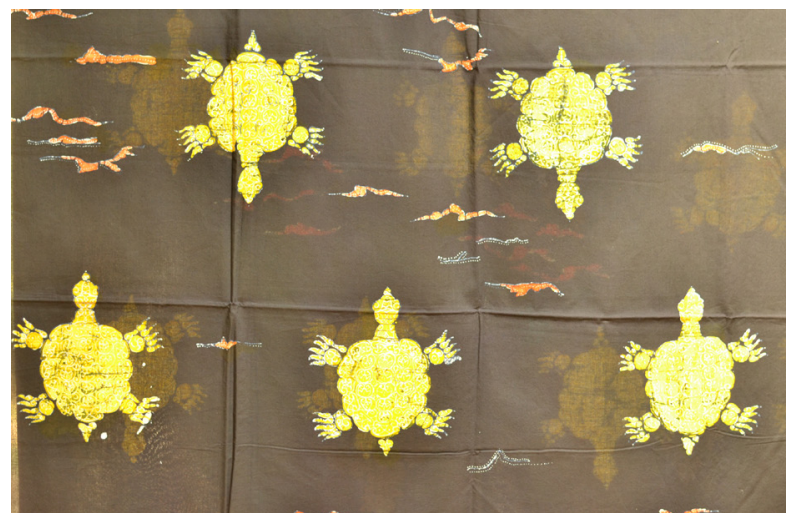

Fig. 2. Tortoise animals motif (by Dewi Irawati) (Author's Documentation, 2019)

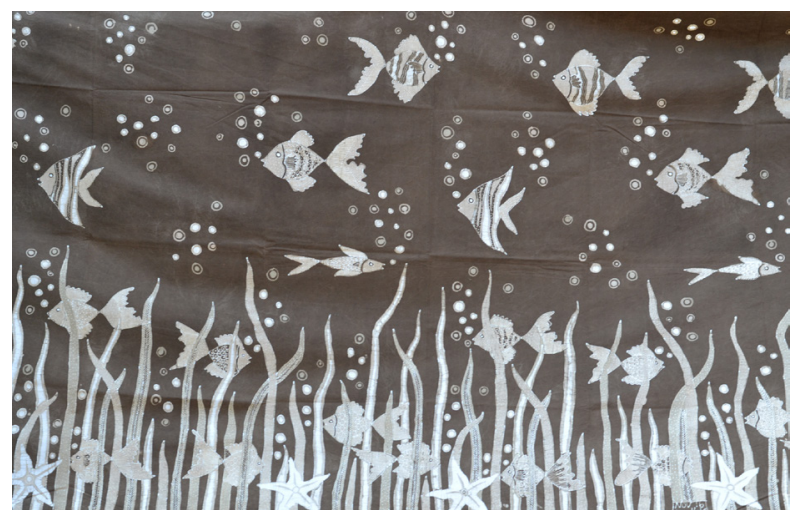

Fig. 3. Fish Motif (by Alfiyah) (Author's Documentation, 2019)

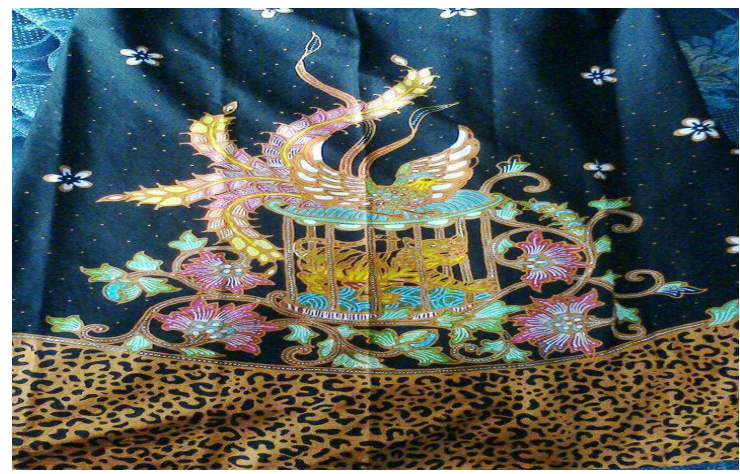

Fig. 4. Tiger motif (by Alfiyah) (Author's Documentation, 2019) 


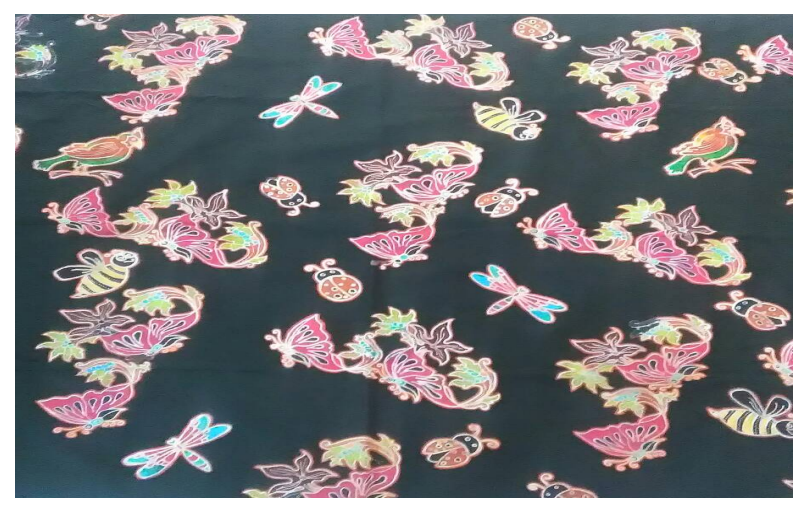

Fig. 5. Insect motif (by Titik Susanti) (Author's Documentation, 2019)

\subsubsection{Plant Motif}

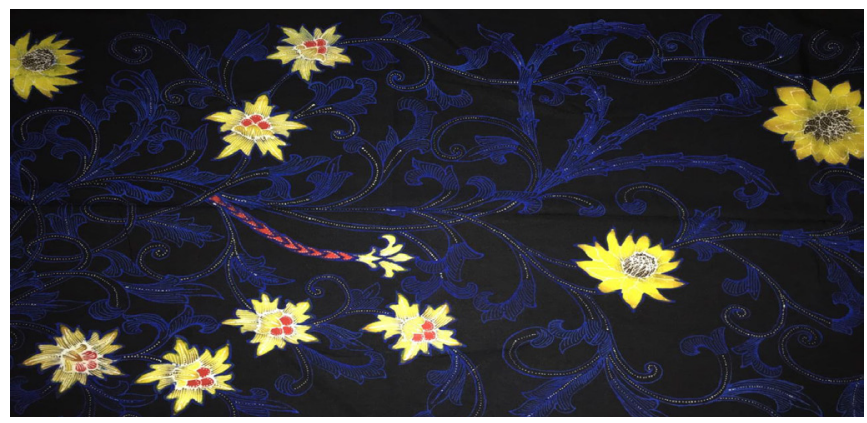

Fig. 6. Tassels leaves (by Suyanti) (Author's Documentation, 2019)

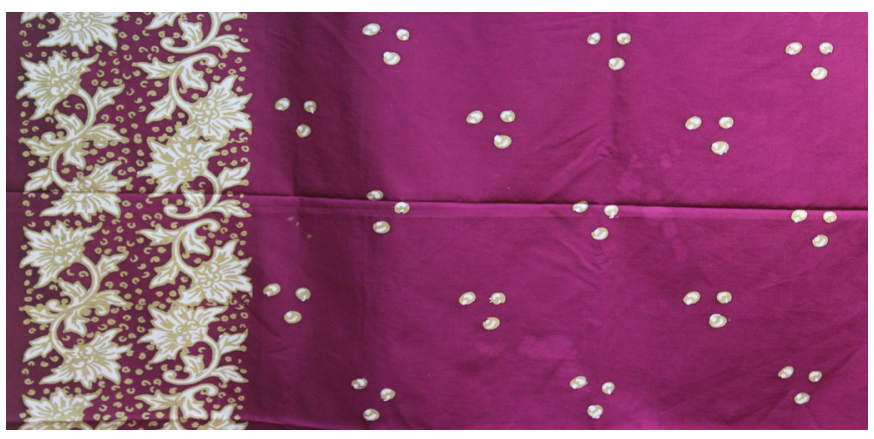

Fig. 7. Wuni Fruit Motif (by Dewi Irawati) (Author's Documentation, 2019) 


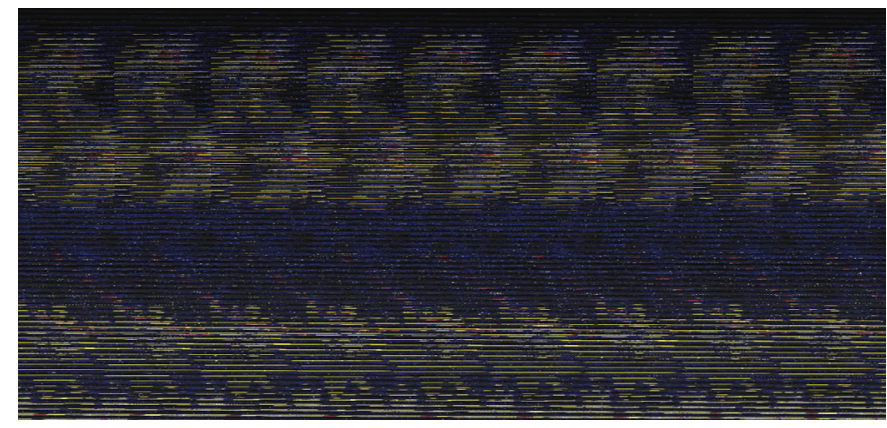

Fig. 8. Sun Flower Motif (by Lina) (Author's Documentation, 2019)

\subsubsection{Natural Objects}

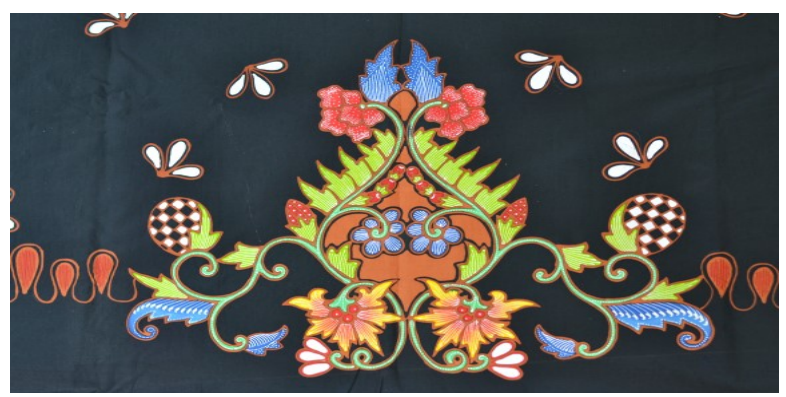

Fig. 9. Jepara Mountain Motif (by Windy) (Author's Documentation, 2019)

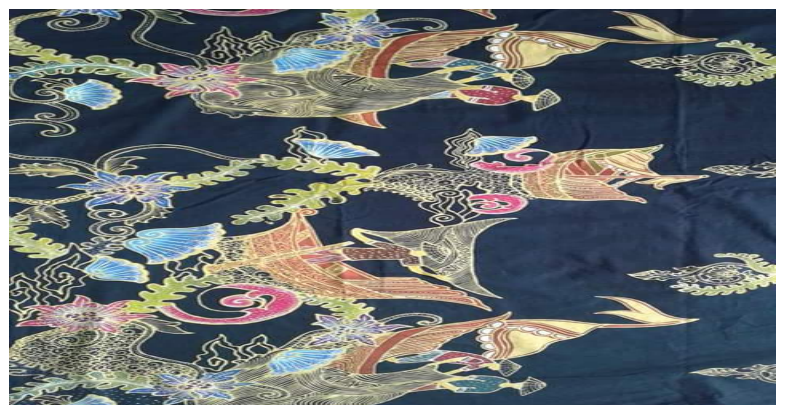

Fig. 10. Karimunjawa Sea Wave (by April) (Author's Documentation, 2019) 


\subsection{Natural Motif: Symbols of Environmental Awarness}

Environmental issues are currently under discussion. This is indicated by global warming problems, forest destruction, sea pollution, and illegal animal hunting. Batik as an art and cultural product can be a medium to deliver a message. Through batik motifs with natural elements we can deliver a message about the importance of environmental preservation so that nature remains sustainable [22]. Jepara batik craftsmen try to give symbolic messages about environmental preservation efforts through their batik motif design as the media. Some batik motif designs with natural elements can be classified as follows:

\subsubsection{Animal Motifs}

Jepara batik with animal motifs has quite a lot of types such as peacock motifs, turtle motifs, butterfly motifs, sea fish motifs, tiger motifs, and insect motifs. First, the peacock's motif was inspired by peacocks in Jepara Regency Hall [23]. Peacock is protected animals because of the number is getting smaller. Using peacocks as batik motifs can be interpreted as an awarness symbol of the craftsmen for peacock preservation that are increasingly threatened. Second, the turtle motif inspired by turtle animals as Jepara icons that is a giant statue of a tortoise [24]. Tortoise as batik motif is a symbol of the craftsman's awaeness for the turtles preservation. Turtles are protected animals in Indonesia because the numbers are less and less.

Third, butterfly motifs are inspired by butterfly varieties, which is one of the animals famous for its beauty and loveliness [25]. Using butterflies as batik motif is as a symbol of the craftsman's awarness for the butterflies preservation. They give a message that butterflies existence must remain sustainable because they are very important in the food chain process. Fourth, marine fish motifs inspired by the varieties of marine life in Jepara [26]. Using sea fish as motifs is a symbol of the craftsmen's awarness for the preservation of Jepara marine life varieties, especially fish. Marine life varieties in Jepara is very beautiful, especially those in Karimunjawa. Marine life that is always sustainable will be very beneficial for humans and especially marine dweller including fish. The craftsmen are trying to deliver a message for people to protect the environment, especially the sea which has a close relationship with Jepara people.

Fifth, tiger motif that is inspired by the rich traditions of Jepara that is the craft of a Caged Tiger Kurung [27]. Tiger or leopard is a Javanese endemic animal, especially Javan leopard which can still be found today in Muria mountain (Jepara border with Pati). This animal is rare and endangered. Using tigers as batik motifs for craftsmen is also a symbol of their concern for the preservation of endangered tigers in Jepara. Sixth, insect motifs inspired by biodiversity in Jepara, one of it is insect [28]. Using insects as batik motifs as a symbol of the craftsman's concern for the animal preservation that is insects because insects have an important role for the ecosystem that is beneficial for humans and the environment.

\subsubsection{Plant Motif}

Jepara Batik also uses motifs from various types of plants, namely jumbai leaf motifs, wuni fruit motifs, and sunflower motifs. First, jumbai leaf motifs are a picture of sweet potatoes' leaves [29]. Using jumbai leaves as batik motifs is as the craftsmen's concern for jumbai leaves preservation or more specifically the sweet potatoes which are rarely planted and consumed today. Jumbai leaf motif reminds us about preserving the sweet potatoes by increasing the consumption. Second, the motif of wuni fruit was inspired by wuni fruit as R. A. Kartini favorite. Wuni trees are still exist in Jepara Regency Hall [30] and as a 
symbol of the craftsmen's concern for wuni sustainability in Jepara. Using wuni fruit motif is as one of Jepara characteristics so that it is not extinct in the future.

Third, sunflower motif inspired by sunflowers beauty. Sunflowers can live in low or high land that get adequate sunlight fit to Jepara's geographical location [31]. Using sunflowers as batik motifs is as a concern symbol of the sunflowers existence as beautiful plants and beneficial for health.

\subsubsection{Natural Objects}

Jepara Batik uses natural objects elements in batik motifs, for example Jepara mountain and Karimunjawa sea wave motif. First, Jepara mountain motif inspired by Jepara natural conditions that is the mountains [32]. Using Jepara mountain as a batik motif is as a symbol of environmental sustainability concern, especially in the mountainous region. The craftsmen give messages to us to love nature. Second, Karimunjawa sea wave motif is inspired by the fishermen living, with a stylized form of waves. Jepara as a coastal city has very beautiful islands (Karimunjawa) with beautiful waves [33]. Using waves as batik motifs is a concern symbol for sea preservation while preserving the beauty of Karimunjawa Sea.

\section{Conclusion}

Although it still needs proof, the existence of batik based on the oral tradition can be traced from the era of Queen Kalinyamat with Kalyaga batik cloth discovery in around the 16th century. During its development, in the Kartini period, Jepara batik was influenced by Mataraman batik. Kartini is an important figure in the development and introduction of Jepara batik. He taught children and residents how to make batik. After Kartini era, batik activities began to fade and just appeared in the early 21 st century. The pioneer was Suyanti who later founded batik community. Jepara batik development is characterized by the application of batik motifs from various natural motifs. One of batik motifs that developed was natural motifs (land and sea). These natural motifs are classified into animal, plant, and natural object motifs. The use of natural batik motifs contains symbolic meaning of the craftsman's concern for the preservation and sustainability of the environment. Through those natural motifs, the message delivered is the importance of nature conservation efforts for Jepara people.

\section{Acknowledgement}

The research is funded by Directorate of Research and Community Service (DRPM) Higher Education (DIKTI) Repbulic of Indonesia in 2020 budget year.

\section{References}

1. Susanto, Seni Kerajinan Batik Indonesia (1973)

2. Doellah, Santosa, Batik: Pengaruh Zaman dan Lingkungan (2002)

3. Toer, Pramoedya Ananta, Panggil Aku Kartini Saja (2000)

4. Alamsyah, Siti Maziyah, Agustinus Supriyono, Natutal Coloring as a Coloring Material for Batik Craft in Jepara (2019)

5. Syamsudin, H., Metodologi Sejarah (2007)

6. Basuki, S., Metode Penelitian (2006)

7. Koentjaraningrat., Metode Penelitian Masyarakat (1997)

8. Garraghan, Gilbert., A Guide to Historical Method (1947) 
9. Herlina, Nina., Metode Sejarah (2008)

10. Alamsyah, Siti Maziyah, Agustinus Supriyono, "Perkembangan Motif Batik Jepara Tahun 2008-2019: Identitas Baru Jepara Berbasis Kearifan Lokal", Jurnal Sejarah Citra Lekha, Vol. 5 (1) (2020)

11. Zoetmulder, Kamus Jawa Kuna - Indonesia (2000)

12. Alamsyah, Siti Maziyah, Agustinus Supriyono, "Perkembangan Motif Batik Jepara Tahun 2008-2019: Identitas Baru Jepara Berbasis Kearifan Lokal", Jurnal Sejarah Citra Lekha, Vol. 5 (1) (2020)

13. Alamsyah, Siti Maziyah, Agustinus Supriyono, "Perkembangan Motif Batik Jepara Tahun 2008-2019: Identitas Baru Jepara Berbasis Kearifan Lokal", Jurnal Sejarah Citra Lekha, Vol. 5 (1) (2020)

14. Alamsyah, Siti Maziyah, Agustinus Supriyono, \& Sri Indrahti., Batik Jepara: Identitas dan Perkembangannya (2019)

15. Alamsyah, A, "Kerajinan Batik dan Pewarnaan Alami” Endogami: Jurnal Ilmiah Kajian Antropologi, Vol. 1 (2) 2018

16. Alamsyah, Siti Maziyah, Agustinus Supriyono, \& Sri Indrahti., Batik Jepara: Identitas dan Perkembangannya (2019)

17. Gustami, SP., Nukilan Seni Ornamen Indonesia (1980)

18. Sunaryo, A., Ornamen Nusantara Kajian Khusus tentang Ornamen Indonesia (2009)

19. D.S, Kartika., Seni Rupa Modern (2004)

20. Purwanto, Revitalisasi Nilai Pendidikan Seni Batik (2011)

21. Estyrantika, Dila., Karakteristik Estetik Ornamen Batik Karya Studio Gendhis Jepara (2018)

22. Syakir., "Ekspresi Seni Berbasis Lingkungan Pesisir", Indonesian Journal of Conservation, Vol. 07 (02), (2018)

23. Wawancara Suyanti Djatmiko, 26 Juni 2019

24. Wawancara Dewi Irawati, 25 Juni 2019

25. Wawancara Alfiyah, 25 Juni 2019

26. Wawancara Alfiyah, 25 Juni 2019

27. Wawancara Alfiyah, 25 Juni 2019

28. Wawancara Titik Susanti, 26 Juni 2019

29. Wawancara Suyanti Djatmiko, 26 Juni 2019

30. Wawancara Dewi Irawati, 25 Juni 2019

31. Wawancara Nurullina, 27 Juni 2019

32. Wawancara Windy, 25 Juni 2019

33. Wawancara April. 28 Juni 2019 